\title{
Studies in the FR901483 tricyclic skeleton synthesis and a new approach to the perhydropyrrolo[2,1-i]indole ring system
}

\author{
Faïza Diaba, Eva Ricou, Daniel Solé, Elisabet Teixidó, Nativitat Valls, and Josep Bonjoch* \\ Laboratori de Química Orgànica, Facultat de Farmàcia, Universitat de Barcelona, Av. Joan \\ XXIII s/n,08028-Barcelona, Spain \\ E-mail: josep.bonjoch@ub.edu
}

\section{Dedicated with admiration to Professor Joan Bosch on his $60^{\text {th }}$ anniversary}

\begin{abstract}
Palladium- and radical-mediated cyclizations from $N$-(2-bromoprop-2-enyl)-1azaspiro[4.5]decanes were studied, leading to the formation of azatricyclic derivatives embodying 7,10a-methanopyrrolo[1,2-a] azocine or a pyrrolo[2,3-i]indole framework depending on the reaction conditions
\end{abstract}

Key words: Palladium, radical cyclization, Heck reaction, nitrogen heterocycles, spirane derivatives

\section{Introduction}

The immunosuppressant FR901483 (Scheme 1) was isolated by a Fujisawa group in 1996, ${ }^{1,2}$ who determined the structure by X-ray crystallography and the absolute configuration was eventually assigned when Snider achieved the enantiocontrolled total synthesis in $1999 .^{3}$ From a structural point of view, the most conspicuous feature of FR901483 is an azatricyclic ring system consisting of the combined morphan and indolizine nuclei sharing the piperidine ring.

In recent years several groups have succeeded in synthesizing the FR901483. ${ }^{3-8}$ Four of them (Snider, ${ }^{3}$ Sorensen, ${ }^{4}$ Ciufolini, ${ }^{5}$ and Brummond ${ }^{6}$ ) achieved the enantioselective synthesis of the natural enantiomer, while Funk's ${ }^{7}$ and Fukuyama's ${ }^{8}$ syntheses were developed in the racemic series. In all reported routes, a functionalized 1-azaspiro[4.5]decan-8-one was used as an intermediate to build the azatricyclic core of the target, using an aldol process whose regioselectivity is sensitive to the substitution pattern and reaction conditions.

With the aim of approaching the FR901483 framework ${ }^{10}$ through a regioselective ring closure from an azaspiro[4.5]decan-8-one, we decided to prepare the azaspiranic enone 1 with the idea of forming the bridge either on the carbonyl $\alpha^{\prime}$ position, the double bond acting as a blocking group (path a) or on the double bond, after reduction of the enone group, (path b) (Scheme 1). In the 
former case we would explore our $\operatorname{Pd}(0)$-catalyzed intramolecular coupling of amino-tethered vinyl halides and ketone enolates ${ }^{11}$ as the methodology for the synthesis of the target nitrogen heterocycle using an enone as the substrate. Path $b$, on the other hand, would lead to a reversed regioselectivity, enabling us to study the feasibility of a radical cyclization either through a direct 6-endo or 5-exo process followed by a rearrangement of the initially-formed homoallyl radical, via a reversible 3-exo-trig cyclization, to give the corresponding six-membered ring. ${ }^{12}$

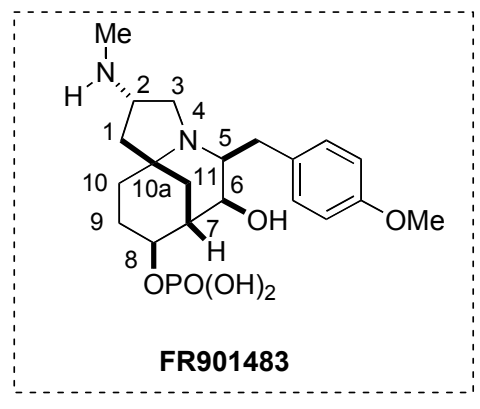

Scheme 1

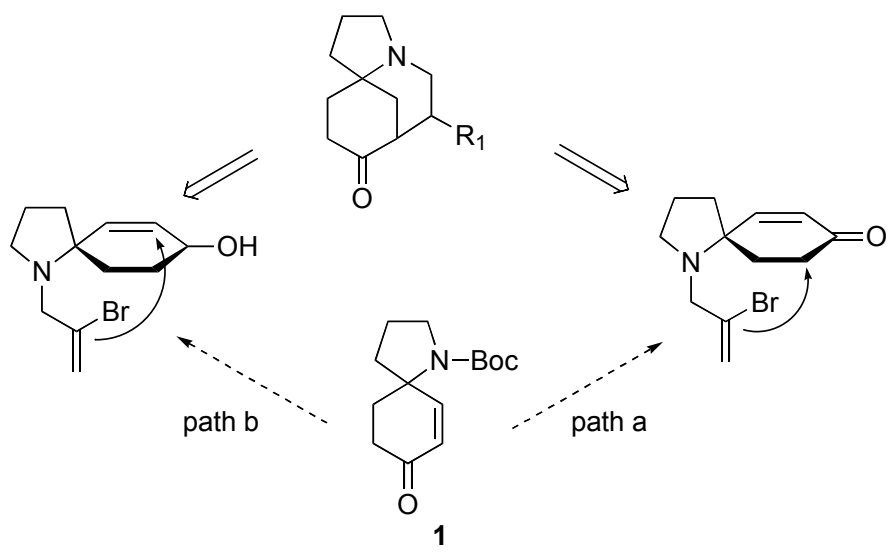

\section{Results and Discussion}

To access the tricyclic skeleton of FR901483 through the proposed methodology we required a cyclization precursor embodying the 1-azaspiro[4.5]dec-6-en-8-one framework (i.e. 1). Although we have recently described an approach to obtain compounds of this type in their enantiopure form, ${ }^{13}$ for this study we prepared compound $\mathbf{1}$ in its racemic form. Our protocol to assemble this azabicyclic system was inspired by Kawahara and Nagumo's procedure ${ }^{14}$ for preparing spirolactams from proline derivatives, based on the alkylation of a proline derivative followed by some functional group interconversion steps and a final aldol cyclization step.

The synthesis (Scheme 2) starts with the alkylation of the L-proline derivative 2 with 4bromo-1-butene using 1.15 eq of LDA to afford racemic $3(64 \%){ }^{15}$ The synthetic sequence 3 П $\mathbf{6}$ involves conversion of ester $\mathbf{3}$ to aldehyde $\mathbf{5}$ through a reduction-oxidation process, followed by Wacker oxidation of the terminal alkene to give the keto aldehyde $\mathbf{6}$. Aldol condensation and succesive elimination process in the ketol intermediate gave cyclohexenone $\mathbf{1}$, in accordance with the recently reported protocol. ${ }^{13}$ 


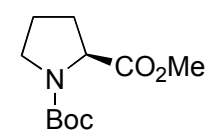

2

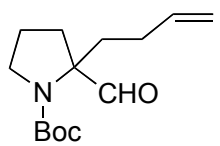

5
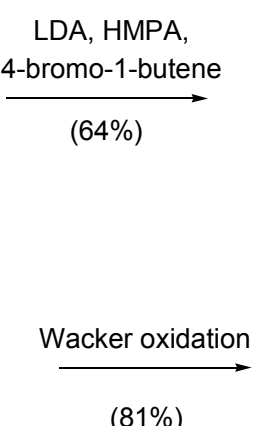

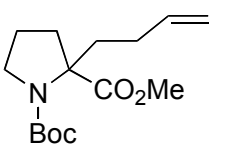

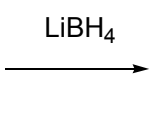

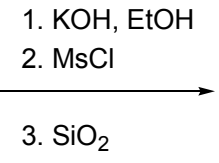

(ref 13)

4
TPAP, NMO

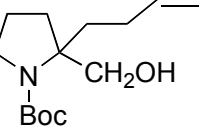

(83\% for two steps)

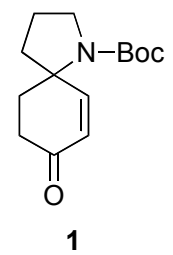

Scheme 2. Synthesis of the azaspiranic intermediate 1.

Removal of the Boc group and alkylation of the secondary amine with 2,3-dibromopropene provided the aminotethered ketone vinyl halide 7, which was submitted to the Pd promoted cyclization in presence of $\mathrm{KOPh}^{11 \mathrm{c}}$ (Scheme 3). Treatment of vinyl halide 7 with 0.2 equiv of $\mathrm{Pd}\left(\mathrm{PPh}_{3}\right)_{4}$ and 2.5 equiv of $\mathrm{KOPh}$ in refluxing THF gave a mixture of tricyclic enone $8(21 \%$ yield) and tricyclic ketone $9(12 \%)$. It became clear from this result that the use of a base to form the enolate does not allow the regiocontrol in the cyclization step, since the vinylpalladium intermediate species reacted with both the enolate and enone double bonds. ${ }^{16}$ In the latter case the reaction evolved through a Heck reductive process. The two compounds formed were separated and their structure elucidated by 2D NMR spectra (see Table 1). Compound 9 was obtained in better yield (44\%) when the same precursor 7 was subjected to a classical Heck reaction conditions $\left[\mathrm{Pd}(\mathrm{OAc})_{2}, \mathrm{PPh}_{3}, \mathrm{Et}_{3} \mathrm{~N}\right]$. Operating from the vinyl bromide $\mathbf{1 1}$ the yield increased to $54 \%$.

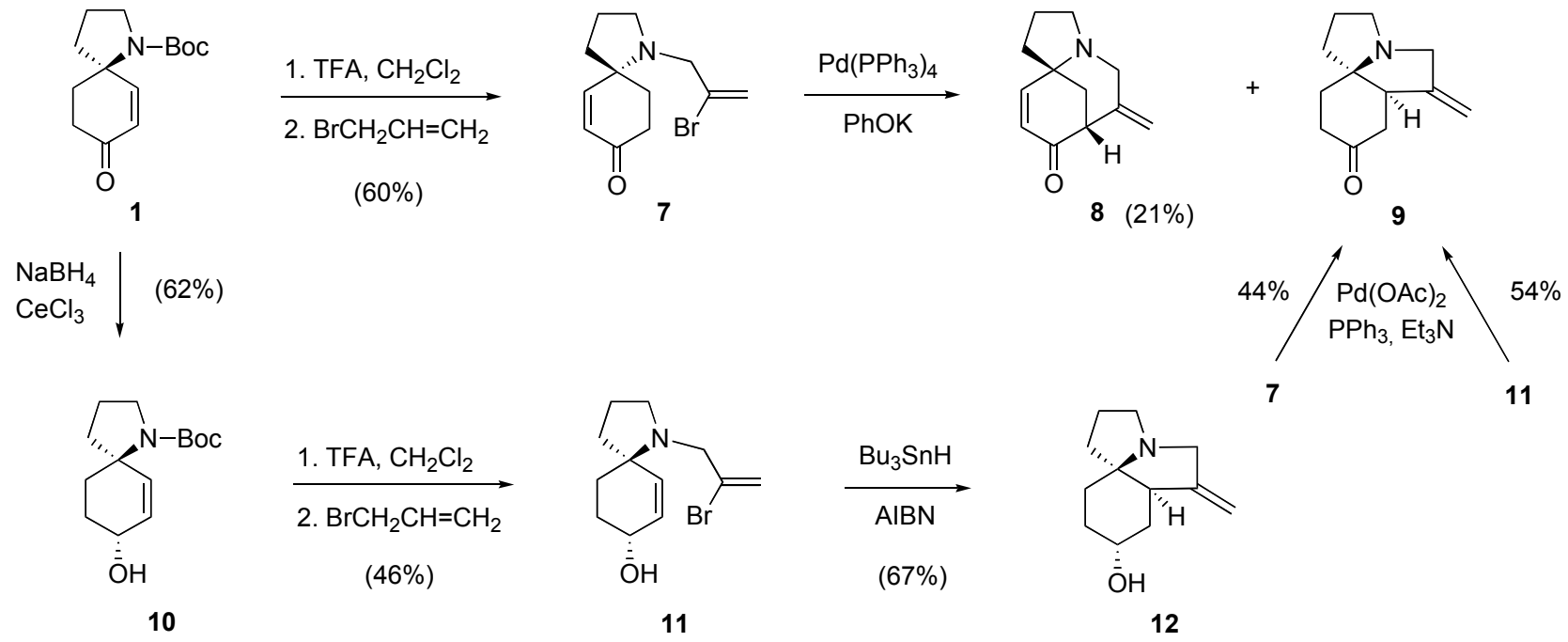

Scheme 3. Palladium- and tributylstannane-promoted cyclization of vinyl bromides $\mathbf{7}$ and $\mathbf{1 1}$. 
Although this ring-forming reaction led to the azatricyclic compound $\mathbf{8}$ and constitutes a novel approach to the heterocyclic system found in FR901483, the low regioselectivity (2 to 1) together with the poor yield in the synthesis of the bridged azatricyclic compound, via the intramolecular palladium-catalyzed enolate-driven cross coupling between the vinyl halide and the enone, induced us to discard this approach. Thus we turned our attention to Path $b$ using the same azaspiranic intermediate $\mathbf{1}$.

As we mentioned before, we were curious to see if a radical process from vinyl bromide 11 through a homoallyl-cyclopropylmethyl radical could be an entry to the FR901483 framework. Reduction of enone 1 with $\mathrm{NaBH}_{4} / \mathrm{CeCl}_{3}$ stereoselectively gave the allylic alcohol 10, which after deprotection and alkylation with 2,3-dibromopropene provided the radical precursor 11. Subjection of the vinyl bromide 11 to standard tin hydride conditions promoted only the 5-exo radical cyclization to give 12, no bridged product $\mathbf{E}$ being observed (Scheme 4).

The course of the reaction may be influenced by steric factors. Indeed, the vinyl radical initially formed from the conformationally mobile $\mathbf{1 1}$ could lead to two conformationally different homoallyl radicals (A and $\mathbf{B}$ ), but only homoallyl radical $\mathbf{B}$ could evolve to afford the cyclopropylmethyl radical (B $\Pi \mathbf{C}$ process) required for the formation of the six-membered ring intermediate $\mathbf{D}$, from which $\mathbf{E}$ could be obtained.

Considering that the only conformation detected for compound $\mathbf{1 2}$ was that corresponding to a trans-diequatorial conformational relationship between the hydroxyl group and the nitrogen atom, as suggested by the NMR experiments (Table 1), we assumed the same conformation for its radical precursor $\mathbf{A}$. This may suggest that one of the reasons for the non-formation of compound $\mathbf{E}$ is the inaccessibility of the correct chair conformation $\mathbf{B}$ in the first radical formed. In turn, the lack of reactivity in the homoallyl radical $\mathbf{A}$ to the corresponding rearranged radical is due to steric reasons, as the conformation depicted in Scheme 4 shows, and to the fact that a conformational change to $\mathbf{B}$ is not available in the time-scale of the radical processes.
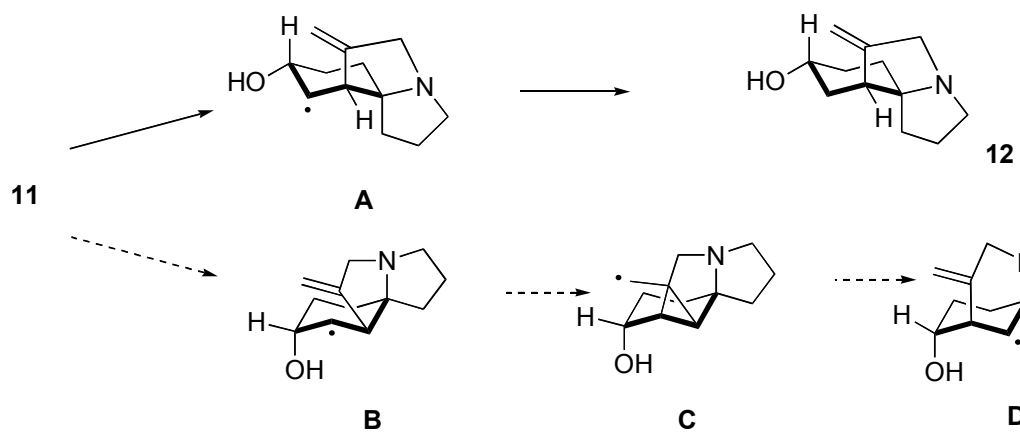

\section{Scheme 4}

Table 1 shows the NMR data of the three azatricyclic compounds reported here. Comparison of the NMR values of protons and carbons in the $\mathrm{C}(3)-\mathrm{C}(5)-\mathrm{C}(10 \mathrm{a})$ domain reveals significant differences (Table 1). Most notably, the spirane carbon $\mathrm{C}-10 \mathrm{a}$ of the bridged compound 8 resonates at $\delta$ 58.3, whereas that of fused compounds 9 and $\mathbf{1 2}$ appears at $\delta$ 71.6. 
Table 1. NMR data of azatricyclic compounds $\mathbf{8 ,}, \mathbf{9}$, and $\mathbf{1 2}$

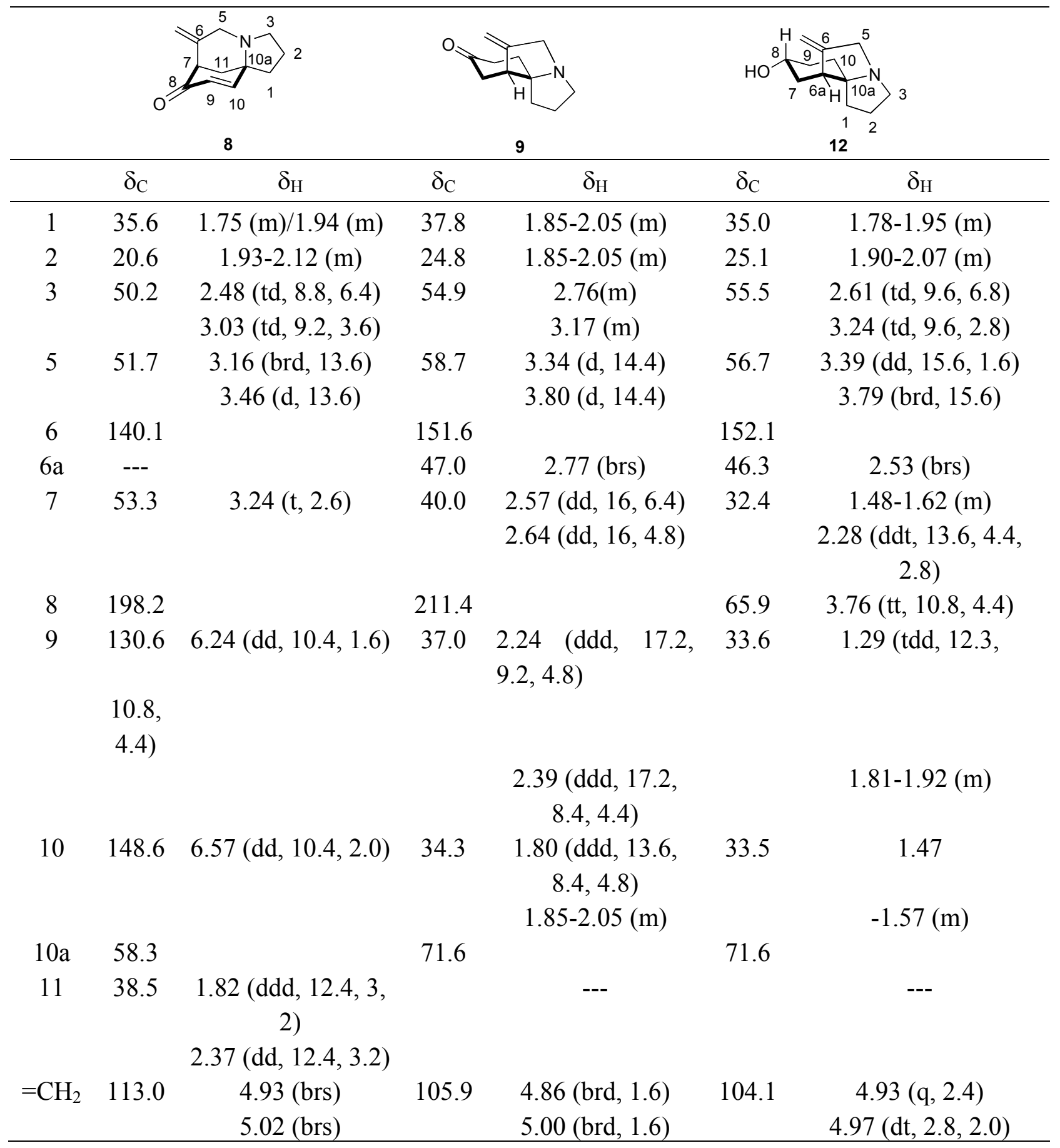

${ }^{1} \mathrm{H}$ and ${ }^{13} \mathrm{C}$ NMR spectra were recorded in $\mathrm{CDCI}_{3}$ at $400 \mathrm{MHz}$ and $100 \mathrm{MHz}$, respectively. Assignments were arded by gCOSY, gHSQC, and gHMBC spectra.

The relative configuration of $\mathbf{1 2}$ was inferred from the pattern of the two methine proton coupling constants of the stereogenic carbons at C-6a and C-8. 
In summary, although the attempts to introduce a regioselective formation of the FR901483 azatricyclic framework have not been very fruitful, the easy formation of the tricyclic system of perhydropyrrolo[2,1-i]indole ${ }^{17}$ could be useful in the development of new synthetic routes to cylindricine $^{18}$ and lepadiformine alkaloids ${ }^{19}$ embodying the related azatricyclic framework of perhydropyrrolo[2,1-j]quinoline.

\section{Experimental Section}

General Procedures. ${ }^{1} \mathrm{H}$ and ${ }^{13} \mathrm{C}$ NMR spectra were recorded in $\mathrm{CDCl}_{3}$ solution. Chemical shifts are reported as $\delta$ values (ppm) relative to internal $\mathrm{Me}_{4} \mathrm{Si}$. Infrared spectra were recorded on a Nicolet 205 FT-IR spectrophotometer. TLC was performed on $\mathrm{SiO}_{2}$ (silica gel $60 \mathrm{~F}_{254}$, Merck) or on $\mathrm{Al}_{2} \mathrm{O}_{3}$ (aluminium oxide $60 \mathrm{~F} 254$, Merck). The spots were located by UV light, a $1 \%$ $\mathrm{KMnO}_{4}$ aqueous solution or a $1.5 \% \quad \mathrm{~K}_{2} \mathrm{PtCl}_{6}$ aqueous solution. Unless otherwise noted chromatography refers to flash chromatography and was achieved on $\mathrm{SiO}_{2}$ (silica gel 60, SDS, 230-400 mesh). All reactions were carried out under an argon atmosphere with dry, freshly distilled solvents and under anhydrous conditions. Drying of the organic extracts during the work-up of reactions was performed over anhydrous $\mathrm{Na}_{2} \mathrm{SO}_{4}$.

tert-Butyl 2-methyl 2-(But-3-enyl)pyrrolidine-1,2-dicarboxylate (3). To a solution of diisopropylamine $(4.21 \mathrm{~mL}, 30.1 \mathrm{mmol})$ in THF $(100 \mathrm{~mL})$ was added at $-78^{\circ} \mathrm{C} n$-BuLi $(1.6 \mathrm{M}$ in hexanes, $20 \mathrm{~mL}, 32.1 \mathrm{mmol}$ ) dropwise and the mixture was stirred at this temperature for $10 \mathrm{~min}$. A solution of $2(5.94 \mathrm{~g}, 25.9 \mathrm{mmol})$ and HMPA $(20 \mathrm{~mL}, 129.6 \mathrm{mmol})$ in THF $(30 \mathrm{~mL})$ was added via cannula and stirring was continued for a further $30 \mathrm{~min}$. 4-bromo-1-butene (7.2 g, $51.8 \mathrm{mmol}$ ) was added dropwise at $-78^{\circ} \mathrm{C}$ and the mixture was allowed to reach rt while stirring overnight. The reaction mixture was quenched with a saturated aqueous $\mathrm{NH}_{4} \mathrm{Cl}(50 \mathrm{~mL})$ and extracted with ether $(3 \times 50 \mathrm{~mL})$. The combined organic extracts were washed with brine $(3 \times 50$ $\mathrm{mL}$ ), dried, concentrated and purified by chromatography (hexane/EtOAc 4:1 to 1:1) yielding 3 as a viscous colorless oil $\left(4.7 \mathrm{~g}, 64 \%\right.$ ). IR (neat) 3077, 2975, 2878, 1742, 1700, $1641 \mathrm{~cm}^{-1} ;{ }^{1} \mathrm{H}$ NMR $\left(\mathrm{CDCl}_{3}, 200 \mathrm{MHz}\right) 1.41$ and $1.45\left(2 \mathrm{~s}, 9 \mathrm{H}, \mathrm{CH}_{3}\right), 1.70-2.50(\mathrm{~m}, 8 \mathrm{H}), 3.41(\mathrm{~m}, 1 \mathrm{H}, \mathrm{H}-5)$, $3.70(\mathrm{~m}, 1 \mathrm{H}, \mathrm{H}-5), 3.70\left(\mathrm{~s}, 3 \mathrm{H}, \mathrm{CH}_{3} \mathrm{O}\right), 4.82-5.12\left(\mathrm{~m}, 2 \mathrm{H},=\mathrm{CH}_{2}\right), 5.81(\mathrm{~m}, 1 \mathrm{H},=\mathrm{CH}) ;{ }^{13} \mathrm{C}$ NMR $\left(\mathrm{CDCl}_{3}, 50.3 \mathrm{MHz}\right) 22.6$ and $23.2\left(\mathrm{CH}_{2}\right), 27.9\left(\mathrm{CH}_{2}\right), 28.2$ and $28.3\left(\mathrm{CH}_{3}\right), 33.3$ and $34.3\left(\mathrm{CH}_{2}\right)$, 36.1 and $37.3\left(\mathrm{CH}_{2}\right), 48.4\left(\mathrm{CH}_{2} \mathrm{~N}\right), 52.0\left(\mathrm{CH}_{3} \mathrm{O}\right), 67.2$ and $67.7(\mathrm{C}-2), 79.3$ and $79.8(\mathrm{C}), 114.2$ and $114.4\left(=\mathrm{CH}_{2}\right), 138.0$ and $138.3(=\mathrm{CH}), 153.6$ and $153.8(\mathrm{CO}), 175.1(\mathrm{CO})$. Anal. Calcd for $\mathrm{C}_{15} \mathrm{H}_{25} \mathrm{NO}_{4} .1 / 4 \mathrm{H}_{2} \mathrm{O}$ : C 62.59, $\mathrm{H}$ 8.93, $\mathrm{N} 4.87$; found $\mathrm{C} 62.65, \mathrm{H} 8.69, \mathrm{~N} 4.83$.

tert-Butyl 2-(But-3-enyl)-2-hydroxymethylpyrrolidine-1-carboxylate (4). To a solution of 3 $(4.17 \mathrm{~g}, 14.7 \mathrm{mmol})$ in toluene $(100 \mathrm{~mL})$ at $-78{ }^{\circ} \mathrm{C}$ was added dropwise a solution of DIBAL (1 $\mathrm{M}$ in $\left.\mathrm{CH}_{2} \mathrm{Cl}_{2}, 56.43 \mathrm{~mL}, 56.43 \mathrm{mmol}\right)$. After being stirred at $\mathrm{rt}$ overnight, the reaction mixture was quenched with water $(5 \mathrm{~mL})$, filtered on a celite pad, dried and concentrated to yield alcohol $4(3.5 \mathrm{~g}, 93 \%)$ pure enough to be used in the next step without further purification. An analytical 
sample was obtained by chromatography (hexane/EtOAc 9:1) as a viscous colorless oil. IR (neat) 3400, 3076, 2974, 2877, 1692, $1667 \mathrm{~cm}^{-1},{ }^{1} \mathrm{H} \mathrm{NMR}\left(\mathrm{CDCl}_{3}, 200 \mathrm{MHz}\right) 1.46$ (s, 9H, $\left.\mathrm{CH}_{3}\right), 1.65-$ $2.38(\mathrm{~m}, 8 \mathrm{H}), 3.23-3.55\left(\mathrm{~m}, 2 \mathrm{H}, \mathrm{CH}_{2} \mathrm{~N}\right), 3.65\left(\mathrm{~d}, 2 \mathrm{H}, J=5.4 \mathrm{~Hz}, \mathrm{CH}_{2} \mathrm{OH}\right), 4.85-5.15(\mathrm{~m}, 2 \mathrm{H}$, $\left.=\mathrm{CH}_{2}\right), 5.36(\mathrm{t}, 1 \mathrm{H}, J=5.4 \mathrm{~Hz}, \mathrm{OH}), 5.82(\mathrm{~m}, 1 \mathrm{H},=\mathrm{CH}) ;{ }^{13} \mathrm{C} \mathrm{NMR}\left(\mathrm{CDCl}_{3}, 50.3 \mathrm{MHz}\right) 22.0$ $\left(\mathrm{CH}_{2}\right), 28.4\left(\mathrm{CH}_{3}\right), 28.8\left(\mathrm{CH}_{2}\right), 31.7\left(\mathrm{CH}_{2}\right), 34.0$ and $34.7\left(\mathrm{CH}_{2}\right), 48.7$ and $49.3\left(\mathrm{CH}_{2} \mathrm{~N}\right), 67.3(\mathrm{C}-$ 2), 67.6 and $69.1\left(\mathrm{CH}_{2} \mathrm{OH}\right), 79.9(\mathrm{C}), 114.2\left(=\mathrm{CH}_{2}\right), 138.4(=\mathrm{CH}), 155.9(\mathrm{CO})$. Anal. Calcd for $\mathrm{C}_{14} \mathrm{H}_{25} \mathrm{NO}_{3}$ : C 65.85, H 9.87, N 5.49; found: C 65.93, H 9.91, N 5.43.

tert-Butyl 2-(But-3-enyl)-2-formylpyrrolidine-1-carboxylate (5). To a solution of alcohol 4 (1.08 g, $4.24 \mathrm{mmol})$ in $\mathrm{CH}_{2} \mathrm{Cl}_{2}(80 \mathrm{~mL})$ were added successively $4 \AA$ molecular sieves $(4.6 \mathrm{~g})$, $\mathrm{NMO}(0.77 \mathrm{~g}, 6.37 \mathrm{mmol})$ and TPAP $(0.077 \mathrm{~g}, 0.21 \mathrm{mmol})$ and the mixture was stirred at rt for 5 $\mathrm{h}$. The reaction mixture was diluted with ether, filtered on florisil and concentrated yielding aldehyde 5 (0.95 g, 89\%) as a viscous colorless oil. IR (neat) 3077, 2976, 2932, 2881, 2804, 2702, 1736, 1691, $1641 \mathrm{~cm}^{-1} ;{ }^{1} \mathrm{H} \mathrm{NMR}\left(\mathrm{CDCl}_{3}, 200 \mathrm{MHz}\right) 1.42$ and $1.46\left(2 \mathrm{~s}, 9 \mathrm{H}, \mathrm{CH}_{3}\right), 1.70-$ $2.20(\mathrm{~m}, 8 \mathrm{H}), 3.32-3.80\left(\mathrm{~m}, 2 \mathrm{H}, \mathrm{CH}_{2} \mathrm{~N}\right), 4.90-5.15\left(\mathrm{~m}, 2 \mathrm{H},=\mathrm{CH}_{2}\right), 5.82(\mathrm{~m}, 1 \mathrm{H},=\mathrm{CH}), 9.41$ and $9.51(2 \mathrm{~s}, 1 \mathrm{H}, \mathrm{CHO}) ;{ }^{13} \mathrm{C} \mathrm{NMR}\left(\mathrm{CDCl}_{3}, 50.3 \mathrm{MHz}\right) 22.9$ and $23.6\left(\mathrm{CH}_{2}\right), 28.0\left(\mathrm{CH}_{2}\right), 28.2$ and $28.4\left(\mathrm{CH}_{3}\right), 31.3$ and $31.9\left(\mathrm{CH}_{2}\right), 32.6$ and $33.8\left(\mathrm{CH}_{2}\right), 48.2$ and $48.3\left(\mathrm{CH}_{2} \mathrm{~N}\right), 70.6$ and $70.9(\mathrm{C}-$ 2), 80.0 and $80.9(\mathrm{C}), 114.5$ and $114.7\left(=\mathrm{CH}_{2}\right), 137.8$ and $138.1(=\mathrm{CH}), 153.3(\mathrm{CO}), 199.5$ and 200.1 (CO). Anal. Calcd for $\mathrm{C}_{14} \mathrm{H}_{23} \mathrm{NO}_{3}$ : C 66.37, H 9.15, N 5.53; found: C 66.32, H 9.24, N 5.47 .

tert-Butyl 2-Formyl-2-(3-oxobutyl)pyrrolidine-1-carboxylate (6). A mixture of $\mathrm{CuCl}(0.29 \mathrm{~g}$, $2.9 \mathrm{mmol}), \mathrm{PdCl}_{2}(0.138 \mathrm{~g}, 0.78 \mathrm{mmol})$, water $(1 \mathrm{~mL})$ and $\mathrm{DMF}(15 \mathrm{~mL})$ was stirred at $\mathrm{rt}$ and under an oxygen atmosphere for $1 \mathrm{~h}$. To the resulting mixture was added a solution of aldehyde 5 $(0.70 \mathrm{~g}, 2.8 \mathrm{mmol})$ in DMF $(15 \mathrm{~mL})$ and stirring at $\mathrm{rt}$ under oxygen was prolonged for a further 5 h. The mixture was quenched by the addition of saturated aqueous $\mathrm{NaHCO}_{3}(10 \mathrm{~mL})$, saturated aqueous $\mathrm{NH}_{4} \mathrm{Cl}(10 \mathrm{~mL})$ and extracted with ether/hexane $(1: 1300 \mathrm{~mL})$. The organics were washed with brine, dried and concentrated to yield keto aldehyde $6(0.6 \mathrm{~g}, 81 \%)$ pure enough to be used in the next step without further purification. An analytical sample was obtained by chromatography (hexane/AcOEt 9:1). The NMR data of 6 coincide with those reported for this compound when it was synthesized in an enantiopure form using another methodology. ${ }^{13}$

tert-Butyl 8-Oxo-1-azaspiro[4.5]dec-6-ene-1-carboxylate (1) was prepared from 6 following our previously reported procedure. ${ }^{13}$

1-(2-Bromoprop-2-enyl)-1-azaspiro[4.5]dec-6-en-8-one (7). A mixture of 1 (0.23 g, 0.92 mmol) and TFA $(2.87 \mathrm{~mL}, 37.2 \mathrm{mmol})$ in $\mathrm{CH}_{2} \mathrm{Cl}_{2}(9 \mathrm{~mL})$ was stirred at $\mathrm{rt}$ for $2 \mathrm{~h}$ prior to solvent evaporation. The residue was taken up in $10 \mathrm{~mL}$ of $\mathrm{CH}_{3} \mathrm{CN}$ and 2,3-dibromopropene $(0.16 \mathrm{~mL}$, $1.40 \mathrm{mmol}), \mathrm{K}_{2} \mathrm{CO}_{3}(0.39 \mathrm{~g}, 2.79 \mathrm{mmol})$ and $\mathrm{LiI}(0.013 \mathrm{~g}, 0.09 \mathrm{mmol})$ were added. The resulting mixture was heated overnight at $60{ }^{\circ} \mathrm{C}$, quenched with water $(5 \mathrm{~mL})$ and extracted with $\mathrm{CH}_{2} \mathrm{Cl}_{2}$ $(5 \times 25 \mathrm{~mL})$. The organic extracts were dried, concentrated and the residue purified by chromatography $\left(\mathrm{CH}_{2} \mathrm{Cl}_{2}\right)$ to give pure compound 7 as a viscous yellowish oil $(0.147 \mathrm{~g}, 60 \%)$. IR (neat) 2948, 2809, 1681, $1630 \mathrm{~cm}^{-1} ;{ }^{1} \mathrm{H}$ NMR $\left(\mathrm{CDCl}_{3}, 300 \mathrm{MHz}\right) 1.80-2.16(\mathrm{~m}, 6 \mathrm{H}), 2.40-2.59$ $(\mathrm{m}, 2 \mathrm{H}), 2.82$ and $2.95(2 \mathrm{~m}, 2 \mathrm{H}, \mathrm{H}-2), 3.30\left(\mathrm{~d}, 1 \mathrm{H}, J=15 \mathrm{~Hz}, \mathrm{CH}_{2} \mathrm{~N}\right), 3.35(\mathrm{~d}, 1 \mathrm{H}, J=15.3 \mathrm{~Hz}$, 
$\mathrm{CH}_{2} \mathrm{~N}$ ), 5.52 (brs, $1 \mathrm{H},=\mathrm{CH}_{2}$ ), 5.88 (brs, $1 \mathrm{H},=\mathrm{CH}_{2}$ ), $5.98(\mathrm{dd}, 1 \mathrm{H}, J=10.2,0.6 \mathrm{~Hz}, \mathrm{H}-7$ ), 6.80 $(\mathrm{dd}, 1 \mathrm{H}, J=10.2,1.8 \mathrm{~Hz}, \mathrm{H}-6) ;{ }^{13} \mathrm{C} \mathrm{NMR}\left(\mathrm{CDCl}_{3}, 75.5 \mathrm{MHz}\right) 22.0(\mathrm{C}-3), 29.7\left(\mathrm{CH}_{2}\right), 34.8$ $\left(\mathrm{CH}_{2}\right), 35.8\left(\mathrm{CH}_{2}\right), 50.5(\mathrm{C}-2), 57.8\left(\mathrm{CH}_{2} \mathrm{~N}\right), 63.5(\mathrm{C}-5), 117.0\left(=\mathrm{CH}_{2}\right), 129.6(\mathrm{C}-7), 132.6(\mathrm{C}-$ $\mathrm{Br}), 156.4(\mathrm{C}-6), 199.0(\mathrm{C}=\mathrm{O})$. Anal. Calcd for $\mathrm{C}_{12} \mathrm{H}_{16} \mathrm{BrNO}$ : C 53.35, H 5.97, N 5.18; found: C 53.73, H 6.21, N 4.44 .

6-Methylene-2,3,4,5,6,7-hexahydro-1 $\mathrm{H}, 10 \mathrm{a} H$-7,10a-methanopyrrolo[1,2-a]azocin-8-one (8). To a solution of 7 (35 mg, $0.13 \mathrm{mmol})$ in THF $(5 \mathrm{~mL})$ were added phenol (37 mg, $0.39 \mathrm{mmol}), t$ BuOK solution (1 M in butanol, $0.32 \mathrm{~mL}, 0.32 \mathrm{mmol})$ and $\mathrm{Pd}\left(\mathrm{PPh}_{3}\right)_{4}(30 \mathrm{mg}, 0.026 \mathrm{mmol})$. The resulting mixture was refluxed overnight, then diluted with $\mathrm{CH}_{2} \mathrm{Cl}_{2}(25 \mathrm{~mL})$ and washed with saturated aqueous $\mathrm{NaHCO}_{3}$, aqueous $\mathrm{NaOH}(2 \mathrm{M})$ and brine. The organics were dried, concentrated and the residue purified by chromatography on $\mathrm{Al}_{2} \mathrm{O}_{3}$ (activity II-III, 70-230 mesh) eluting from hexane to 7:3 hexane/EtOAc to give $8(5.1 \mathrm{mg}, 21 \%)$ followed by $\mathbf{9}(3 \mathrm{mg}, 12 \%)$.

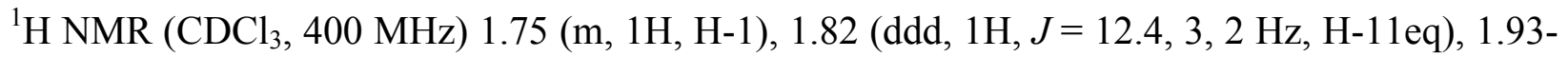
2.12 (m, 2H, $\left.\mathrm{CH}_{2}-2\right), 1.94$ (m, 1H, H-1), 2.37 (dd, 1H, J=12.4, $3.2 \mathrm{~Hz}, \mathrm{H}-11 \mathrm{ax}$ ), 2.48 (td, 1H, $J$ $=8.8,6.4 \mathrm{~Hz}, \mathrm{H}-3), 3.03(\mathrm{td}, 1 \mathrm{H}, J=9.2,3.6 \mathrm{~Hz}, \mathrm{H}-3), 3.16(\mathrm{brd}, 1 \mathrm{H}, J=13.6 \mathrm{~Hz}, \mathrm{H}-5), 3.24(\mathrm{t}$, $1 \mathrm{H}, J=2.6 \mathrm{~Hz}, \mathrm{H}-7), 3.46$ (d, $1 \mathrm{H}, J=13.6 \mathrm{~Hz}, \mathrm{H}-5), 4.93$ (brs, $\left.1 \mathrm{H},=\mathrm{CH}_{2}\right), 5.02$ (brs, $1 \mathrm{H},=\mathrm{CH}_{2}$ ), $6.24(\mathrm{dd}, 1 \mathrm{H}, J=10.4,1.6 \mathrm{~Hz}, \mathrm{H}-9), 6.57$ (dd, $1 \mathrm{H}, J=10.4,2 \mathrm{~Hz}, \mathrm{H}-10) ;{ }^{13} \mathrm{C} \mathrm{NMR}\left(\mathrm{CDCl}_{3}, 100\right.$ MHz) 20.6 (C-2), 35.6 (C-1), 38.5 (C-11), 50.2 (C-3), 51.7 (C-5), 53.3 (C-7), 58.3 (C-10a), 113.0 $\left(\mathrm{H}_{2} \mathrm{C}=\right)$, 130.6 (C-9), 140.1 (C-6), 148.6 (C-10), 198.2 (CO). HRMS (ESI) m/z calcd for $\mathrm{C}_{12} \mathrm{H}_{16} \mathrm{NO} 190.1226[\mathrm{M}+\mathrm{H}]^{+}$; found 190.1222. For analytical data of 9, see below.

(6aRS,10aRS)-6-Methylene-2,3,5,6,6a,7,9,10-octahydro-1 $H$-pyrrolo[2,1-i]indol-8-one

(9).

From 7. Palladium acetate (43 $\mathrm{mg}, 0.19 \mathrm{mmol})$ was added to a solution of 7 (51 $\mathrm{mg}, 0.19 \mathrm{mmol})$, $\mathrm{PPh}_{3}(0.22 \mathrm{~g}, 0.83 \mathrm{mmol})$ and $\mathrm{Et}_{3} \mathrm{~N}(0.2 \mathrm{~mL}, 1.43 \mathrm{mmol})$ in $\mathrm{CH}_{3} \mathrm{CN}(5 \mathrm{~mL})$ and the mixture was refluxed for $4 \mathrm{~h}$. Saturated aqueous $\mathrm{Na}_{2} \mathrm{CO}_{3}$ was added and the mixture extracted with $\mathrm{CHCl}_{3}$ $(5 \times 25 \mathrm{~mL})$. The combined organic extracts were dried, concentrated and purified by chromatography $\left(\mathrm{CH}_{2} \mathrm{Cl}_{2}\right.$ to $5 \% \mathrm{MeOH}$ in $\left.\mathrm{CH}_{2} \mathrm{Cl}_{2}\right)$ to give pure 9 (16 mg, 44\%). IR (neat): 2949, 2866, 1717, $1666 \mathrm{~cm}^{-1} ;{ }^{1} \mathrm{H} \mathrm{NMR}\left(\mathrm{CDCl}_{3}, 400 \mathrm{MHz}\right) 1.80$ (ddd, $\left.1 \mathrm{H}, J=13.6,8.4,4.8 \mathrm{~Hz}, \mathrm{H}-10\right)$, 1.85-2.05 (m, 5H), 2.24 (ddd, 1H, $J=17.2,9.2,4.8 \mathrm{~Hz}, \mathrm{H}-9), 2.39$ (ddd, 1H, $J=17.2,8.4,4.4$ Hz, H-9), 2.57 (dd, 1H, $J=16.0,6.4$ Hz, H-7), 2.64 (dd, 1H, $J=16.0,4.8 \mathrm{~Hz}, \mathrm{H}-7), 2.76$ (m, 1H, H-3), 2.77 (brs, 1H, H-6a), 3.17 (m, 1H, H-3), 3.34 (d, 1H, J=14.4 Hz, H-5), 3.80 (d, 1H, J= 14 $\mathrm{Hz}, \mathrm{H}-5), 4.86$ (brd, $\left.1 \mathrm{H}, J=1.6 \mathrm{~Hz}, \mathrm{H}_{2} \mathrm{C}=\right), 5.00$ (brd, $\left.1 \mathrm{H}, J=1.6 \mathrm{~Hz},=\mathrm{CH}_{2}\right) ;{ }^{13} \mathrm{C} \mathrm{NMR}\left(\mathrm{CDCl}_{3}\right.$, 75.5 MHz) 24.8 (C-2), 34.3 (C-10), 37.0 (C-9), 37.8 (C-1), 40.0 (C-7), 47.0 (C-6a), 54.9 (C-3), 58.7 (C-5), $71.6(\mathrm{C}-10 \mathrm{a}), 105.9\left(\mathrm{H}_{2} \mathrm{C}=\right)$, $151.6(\mathrm{C}-6), 211.4(\mathrm{CO})$. HRMS (ESI) $\mathrm{m} / z$ calcd for $\mathrm{C}_{12} \mathrm{H}_{18} \mathrm{NO} 192.1383[\mathrm{M}+\mathrm{H}]^{+}$; found 192.1377.

From 11. Operating as above from $11(26 \mathrm{mg}, 0.095 \mathrm{mmol}), \mathrm{Pd}(\mathrm{OAc})_{2}(6 \mathrm{mg}, 0.029 \mathrm{mmol})$, $\mathrm{PPh}_{3}(16 \mathrm{mg}, 0.062 \mathrm{mmol})$ and $\mathrm{Et}_{3} \mathrm{~N}$ as solvent $(4.3 \mathrm{~mL})$. After $1.5 \mathrm{~h}$ of reflux 9 was isolated $(9.8$ $\mathrm{mg}, 54 \%)$.

tert-Butyl (5RS,8RS)-8-Hydroxy-1-azaspiro[4.5]dec-6-ene-1-carboxylate (10). To a solution of enone 1 (100 mg, $0.40 \mathrm{mmol})$ in THF $(10 \mathrm{~mL})$ at $0{ }^{\circ} \mathrm{C}$ was added $\mathrm{CeCl}_{3}(125 \mathrm{mg}, 0.5 \mathrm{mmol})$ and the mixture was stirred for $5 \mathrm{~min}$. $\mathrm{NaBH}_{4}(20 \mathrm{mg}, 0.5 \mathrm{mmol})$ was added and stirring was 
continued for $5 \mathrm{~min}$ at $0{ }^{\circ} \mathrm{C}$ and $10 \mathrm{~min}$ at $\mathrm{rt}$. The reaction mixture was evaporated to dryness, water $(10 \mathrm{~mL})$ was added and the mixture extracted with $\mathrm{CHCl}_{3}$. The combined organic extracts were dried and concentrated. After chromatography $\left(\mathrm{CH}_{2} \mathrm{Cl}_{2} / \mathrm{MeOH}\right.$ 99.5:0.5) 10 (63 mg, 62\%) was obtained as a viscous colorless oil. IR (neat) $3416,2972,2870,1683 \mathrm{~cm}^{-1} ;{ }^{1} \mathrm{H} \mathrm{NMR}\left(\mathrm{CDCl}_{3}\right.$, $400 \mathrm{MHz}) 1.42$ and $1.43\left(2 \mathrm{~s}, 9 \mathrm{H}, \mathrm{CH}_{3}\right), 1.46-1.67(\mathrm{~m}, 2 \mathrm{H}), 1.77(\mathrm{~m}, 3 \mathrm{H}), 1.98(\mathrm{~m}, 1 \mathrm{H}), 2.12(\mathrm{~m}$, $1 \mathrm{H}), 2.21$ and $2.41(2 \mathrm{t}, 1 \mathrm{H}, J=13.6 \mathrm{~Hz}), 3.35(\mathrm{~m}, 1 \mathrm{H}, \mathrm{H}-2), 3.49$ and $3.56(2 \mathrm{~m}, 1 \mathrm{H}, \mathrm{H}-2), 4.26$ and 4.44 (2brs, $1 \mathrm{H}, \mathrm{H}-8), 5.45$ and $5.53(2 \mathrm{~d}, 1 \mathrm{H}, J=10 \mathrm{~Hz}, \mathrm{H}-7), 5.63$ and $5.72(2 \mathrm{~d}, 1 \mathrm{H}, J=10$ $\mathrm{Hz}, \mathrm{H}-6) ;{ }^{13} \mathrm{C} \mathrm{NMR}\left(\mathrm{CDCl}_{3}, 100 \mathrm{MHz}\right) 22.2$ and $22.7(\mathrm{C}-3), 28.4$ and $28.6\left(\mathrm{CH}_{3}\right), 30.8(\mathrm{C}-10)$, 32.0 and 32.3 (C-9), 38.6 and 39.5 (C-4), 47.5 and 47.8 (C-2), 61.9 and $62.0(\mathrm{C}-5), 67.0$ and 67.4 (C-8), 79.0 and $79.4(\mathrm{C}), 130.3$ and 130.7 (C-6), 136.0 and 135.5 (C-7), 153.2 (CO). HRMS (ESI) $m / z$ calcd for $\mathrm{C}_{14} \mathrm{H}_{23} \mathrm{NNaO}_{3} 276.1570[\mathrm{M}+\mathrm{Na}]^{+}$; found 276.1565.

(5RS,8RS)-1-(2-Bromoprop-2-enyl)-1-azaspiro[4.5]dec-6-en-8-ol (11). Operating as in the preparation of 7, from allylic alcohol $10(0.273 \mathrm{~g}, 1.08 \mathrm{mmol})$, TFA (3.35 $\mathrm{mL}, 40.1 \mathrm{mmol})$ and $\mathrm{CH}_{2} \mathrm{Cl}_{2}(10 \mathrm{~mL})$. The mixture was concentrated and the residue was treated with 2,3dibromopropene $(0.186 \mathrm{~mL}, 1.62 \mathrm{mmol}), \mathrm{K}_{2} \mathrm{CO}_{3}(0.3 \mathrm{~g}, 2.16 \mathrm{mmol})$ and LiI $(0.015 \mathrm{~g}, 0.108$ mmol) in $\mathrm{CH}_{3} \mathrm{CN}(10 \mathrm{~mL})$. After chromatography $\left(\mathrm{CH}_{2} \mathrm{Cl}_{2}-\mathrm{CH}_{2} \mathrm{Cl}_{2} / \mathrm{MeOH}\right.$ 98:2) pure 11 (0.134 $\mathrm{g}, 46 \%)$ was isolated as a viscous yellowish oil: ${ }^{1} \mathrm{H} \mathrm{NMR}\left(\mathrm{CDCl}_{3}, 400 \mathrm{MHz}\right) 1.10-1.64(\mathrm{~m}, 3 \mathrm{H})$, 1.71-1.90 (m, 4H), $2.11(\mathrm{~m}, 1 \mathrm{H}), 2.77$ and $2.84\left(2 \mathrm{~m}, 2 \mathrm{H}, \mathrm{CH}_{2}-2\right), 3.20(\mathrm{~d}, 1 \mathrm{H}, J=15.6 \mathrm{~Hz}$, $\left.\mathrm{CH}_{2} \mathrm{~N}\right), 3.26\left(\mathrm{~d}, 1 \mathrm{H}, J=15.2 \mathrm{~Hz}, \mathrm{CH}_{2} \mathrm{~N}\right), 4.23(\mathrm{~m}, 1 \mathrm{H}, \mathrm{H}-8), 5.48$ (brs, $\left.1 \mathrm{H},=\mathrm{CH}_{2}\right), 5.53(\mathrm{~d}, 1 \mathrm{H}, J$ $=10 \mathrm{~Hz}, \mathrm{H}-6), 5.77$ (dt, $1 \mathrm{H}, J=10,1.6 \mathrm{~Hz}, \mathrm{H}-7), 5.88$ (brs, $\left.1 \mathrm{H},=\mathrm{CH}_{2}\right) ;{ }^{13} \mathrm{C} \mathrm{NMR}\left(\mathrm{CDCl}_{3}, 75.5\right.$ MHz) 21.8 (C-3), 28.5 (C-10), 31.6 (C-9), 37.8 (C-4), $50.5(\mathrm{C}-2), 57.7\left(\mathrm{CH}_{2} \mathrm{~N}\right), 63.5(\mathrm{C}-5), 67.3$ $(\mathrm{C}-8), 116.3\left(\mathrm{H}_{2} \mathrm{C}=\right), 133.0(\mathrm{C}-6), 133.3(\mathrm{C}-\mathrm{Br}), 134.8$ (C-7). Anal. Calcd for $\mathrm{C}_{12} \mathrm{H}_{18} \mathrm{BrNO}$ : C 52.95, H 6.67, N 5.15; found: C 52.58, H 6.65, N 4.91.

\section{(6aRS,8RS,10aRS)-6-Methylene-2,3,6,6a,7,8,9,10-octahydro-1 $H, 5 H$-pyrrolo[2,1-i]indol-8-ol}

(12). A mixture of $11(21 \mathrm{mg}, 0.077 \mathrm{mmol}), \mathrm{Bu} 3 \mathrm{SnH}(0.034 \mathrm{~mL}, 0.123 \mathrm{mmol})$ and catalytic amount of AIBN (3 mg, $0.018 \mathrm{mmol})$ in benzene $(15 \mathrm{~mL})$ was refluxed for $4 \mathrm{~h}$. The solvent was removed under reduced pressure and the residue purified by chromatography $\left(\mathrm{CH}_{2} \mathrm{Cl}_{2}\right.$ to $\mathrm{CH}_{2} \mathrm{Cl}_{2} / \mathrm{MeOH}$ 97:3 saturated with $\mathrm{NH}_{3}$ ) to provide pure 12 as a white solid (10 mg, 67\%): $\mathrm{mp}$ 108-109 ${ }^{\circ} \mathrm{C}\left(\mathrm{CH}_{2} \mathrm{Cl}_{2} /\right.$ hexane). IR ( $\mathrm{NaCl}$, neat) 3358, 3068, 2926, 2855, $1663 \mathrm{~cm}^{-1}$; ${ }^{1} \mathrm{H} \mathrm{NMR}$ $\left(\mathrm{CDCl}_{3}, 400 \mathrm{MHz}\right) 1.29(\mathrm{tdd}, 1 \mathrm{H}, J=12.3,10.8,4.4 \mathrm{~Hz}, \mathrm{H}-9 \mathrm{ax}), 1.45-1.57$ (m, 2H, $\left.\mathrm{CH}_{2}-10\right)$, 1.48-1.62 (m, 1H, H-7ax), 1.78-1.95 (m, 2H, $\mathrm{CH}_{2}-1$ ), 1.81-1.92 (m, 1H, H-9eq), 1.90-2.07 (m, 2H, $\mathrm{CH}_{2}-2$ ), 2.28 (ddt, 1H, $J=13.6,4.4,2.8 \mathrm{~Hz}, \mathrm{H}-7 \mathrm{eq}$ ), 2.53 (brs, 1H, H-6a), 2.61 (td, 1H, $J=$ 9.6, $6.8 \mathrm{~Hz}, \mathrm{H}-3$ ), 3.24 (td, 1H, $J=9.6,2.8 \mathrm{~Hz}, \mathrm{H}-3$ ), 3.39 (dd, $1 \mathrm{H}, J=15.6,1.6 \mathrm{~Hz}, \mathrm{H}-5$ ), 3.76 (tt, $1 \mathrm{H}, J=10.8,4.4 \mathrm{~Hz}, \mathrm{H}-8 \mathrm{ax}), 3.79$ (brd, $1 \mathrm{H}, J=15.6 \mathrm{~Hz}, \mathrm{H}-5), 4.93$ (q, 1H, $J=2.4 \mathrm{~Hz}$, $\left.=\mathrm{CH}_{2}\right), 4.97\left(\mathrm{dt}, 1 \mathrm{H}, J=2.8,2 \mathrm{~Hz},=\mathrm{CH}_{2}\right) ;{ }^{13} \mathrm{C} \mathrm{NMR}\left(\mathrm{CDCl}_{3}, 50.3 \mathrm{MHz}\right) 25.1(\mathrm{C}-2), 32.4(\mathrm{C}-7)$, 33.5 (C-10), 33.6 (C-9), 35.0 (C-1), 46.3 (C-6a), 55.5 (C-3), 56.7 (C-5), 65.9 (C-8), 71.6 (C-10a), $104.1\left(=\mathrm{CH}_{2}\right), 152.1(\mathrm{C}-6)$. HRMS (ESI) $\mathrm{m} / z$ calcd for $\mathrm{C}_{12} \mathrm{H}_{20} \mathrm{NO} 194.1539[\mathrm{M}+\mathrm{H}]^{+}$; found 194.1538 . 


\section{Acknowledgements}

This research was supported by the Ministry of Education and Science (MEC, Spain)-FEDER through project CTQ2004-04701/BQU. Thanks are also due to the DURSI (Catalonia) for Grant 2005SGR-00442.

\section{References and Footnotes}

1. Sakamoto, K.; Tsujii, E.; Abe, F.; Nakanishi, T.; Yamashita, M.; Shigematsu, N.; Izumi, S.; Okuhara, M. J. Antibiot. 1996, 49, 37.

2. For a review on the synthesis of FR901483, see: Bonjoch, J.; Diaba, F. Studies in Natural Products Chemistry 2005, 32, 3.

3. Snider, B. B.; Lin, H. J. Am. Chem. Soc. 1999, 121, 7778.

4. Scheffler, G.; Seike, H.; Sorensen, E. J. Angew. Chem. Int. Ed. 2000, 39, 4593.

5. Ousmer, M.; Braun, N. A.; Bavoux, C.; Perrin, M.; Ciufolini, M. A. J. Am. Chem. Soc. 2001, $123,7534$.

6. Brummond, K. M.; Hong, S. J. Org. Chem. 2005, 70, 907.

7. Maeng, J.-H.; Funk, R. L. Org. Lett. 2001, 3, 1125.

8. Kan, T.; Fujimoto, T.; Ieda, S.; Asoh, Y.; Kitaoka, H.; Fukuyama, T. Org. Lett. 2004, 6, 2729.

9. For oher synthetic approaches leading to the tricyclic framework of FR901483, see (a) Yamazaki, N.; Suzuki, H.; Kibayashi, C. J. Org. Chem. 1997, 62, 8280. (b) Wardrop, D. J.; Zhang, W. Org. Lett. 2001, 3, 2353. (c) Suzuki, H.; Yamazaki, N.; Kibayashi, C. Tetrahedron Lett. 2001, 42, 3013. (d) Bonjoch, J.; Diaba, F.; Puigbó, G.; Peidró, E.; Solé, D. Tetrahedron Lett. 2003, 44, 8387. (e) Panchaud, P.; Ollivier, C.; Renaud, P.; Zigmantas, S. J. Org. Chem. 2004, 69, 2755. (f) Kropf, J. E.; Meigh, I. C.; Bebbington, W. P.; Weinreb, S. M. J. Org. Chem. 2006, 71, 2046. (g) Simila, S. T. M.; Reichelt, A.; Martin, S. F. Tetrahedron Lett. 2006, 47, 2933.

10. For our previous work in this field, see: (a) Bonjoch, J.; Diaba, F.; Puigbó, G.; Solé, D.; Segarra, V.; Santamaría, L.; Beleta, J.; Ryder, H.; Palacios, J.-M. Bioorg. Med. Chem. 1999, 7, 2891. (b) Puigbó, G.; Diaba, F.; Bonjoch, J. Tetrahedron 2003, 59, 2657. (c) ref 9d.

11. For studies on this methodology, see (a) Solé, D.; Peidró, E.; Bonjoch, J. Org. Lett. 2000, 2, 2225. (b) Solé, D.; Diaba, F.; Bonjoch, J. Org. Chem. 2003, 68, 5746. (c) Solé, D.; Urbaneja, X.; Bonjoch, J. Adv. Synth. Catal. 2004, 346, 1646. See also ref 9d.

12. For six-membered ring formation by vinyl radical cyclization, see: Padwa, A.; Rashatasakhon, P.; Ozdemir, A. D.; Willis, J. J. Org. Chem. 2005, 70, 519 and references therein.

13. Diaba, F.; Ricou, E.; Bonjoch, J. Tetrahedron: Asymmetry 2006, 17, 1437. For a seminal work in this field, see; Auty, J. M. A.; Churcher, I.; Hayes, C. J. Synlett. 2004, 1443. 
14. Nagumo, S.; Matoba, A.; Ishii, Y.; Yamaguchi, S.; Akutsu, N.; Nishijima, H.; Nishida, A.; Kawahara, N. Tetrahedron 2002, 58, 9871.

15. For a synthesis of a related enantiopure 2,2-disubstituted proline, see: Khalil, E. M.; Ojala, W. H.; Pradhan, A.; Nair, V. D.; Gleason, W. B.; Mishra, R. K.; Johnson, R. L. J. Med. Chem. 1999, 42, 628.

16. For a similar dichotomy, see (a) Khan, F. A.; Czerwonka, R.; Reissig, H.-U. Synlett 1996, 533. (b) Khan, F. A.; Czerwonka, R.; Reissig, H.-U. Eur. J. Org. Chem. 2000, 3607.

17. For other approaches to the azatricyclic ring of 12, see: (a) Sato, T.; Nakamura, N.; Ikeda, K.; Okada, M.; Ishibashi, H.; Ikeda, M. J. Chem. Soc., Perkin Trans 1 1992, 2399. (b) Denmark, S. E.; Middleton, D. S. J. Org. Chem. 1998, 63, 1604. (c) Parsons, A. F.; Williams, D. A. J. Tetrahedron 2000, 56, 7217.

18. Swidorski, J. J.; Wang, J.; Hsung, R. P. Org. Lett. 2006, 8, 777 and references therein.

19. (a) Lee, M.; Lee, T.; Eun-Young, K.; Ko, Hyojin; Deukjoon, K.; Sanghee, K. Org. Lett. 2006, 8, 745. (b) Schär, P.; Renaud, P. Org. Lett. 2006, 8, 1569 and references therein. 